\title{
OVERVIEW
}

\section{Endangered river fish: factors hindering conservation and restoration}

\author{
Steven J. Cooke ${ }^{1, *}$, Craig Paukert ${ }^{2}$, Zeb Hogan ${ }^{3}$ \\ ${ }^{1}$ Fish Ecology and Conservation Physiology Laboratory, Department of Biology and Institute of Environmental Science, \\ Carleton University, Ottawa, Ontario K1S 5B6, Canada \\ ${ }^{2}$ United States Geological Survey, Missouri Cooperative Fish and Wildlife Research Unit, Department of Fisheries and \\ Wildlife Sciences, University of Missouri, Columbia, Missouri 65211, USA \\ ${ }^{3}$ Department of Natural Resources and Environmental Science, University of Nevada, Mail Stop 186, 1664 North Virginia \\ Street, Reno, Nevada 89557, USA
}

\begin{abstract}
Globally, riverine fish face many anthropogenic threats including riparian and flood plain habitat degradation, altered hydrology, migration barriers, fisheries exploitation, environmental (climate) change, and introduction of invasive species. Collectively, these threats have made riverine fishes some of the most threatened taxa on the planet. Although much effort has been devoted to identifying the threats faced by river fish, there has been less effort devoted to identifying the factors that may hinder our ability to conserve and restore river fish populations and their watersheds. Therefore, we focus our efforts on identifying and discussing 10 general factors (can also be viewed as research and implementation needs) that constrain or hinder effective conservation action for endangered river fish: (1) limited basic natural history information; (2) limited appreciation for the scale/extent of migrations and the level of connectivity needed to sustain populations; (3) limited understanding of fish/river-flow relationships; (4) limited understanding of the seasonal aspects of river fish biology, particularly during winter and/or wet seasons; (5) challenges in predicting the response of river fish and river ecosystems to both environmental change and various restoration or management actions; (6) limited understanding of the ecosystem services provided by river fish; $(7)$ the inherent difficulty in studying river fish; $(8)$ limited understanding of the human dimension of river fish conservation and management; (9) limitations of single species approaches that often fail to address the broader-scale problems; and (10) limited effectiveness of governance structures that address endangered river fish populations and rivers that cross multiple jurisdictions. We suggest that these issues may need to be addressed to help protect, restore, or conserve river fish globally, particularly those that are endangered.
\end{abstract}

KEY WORDS: Large rivers · Endangered fish · Connectivity $\cdot$ Conservation $\cdot$ Threats Resale or republication not permitted without written consent of the publisher

\section{INTRODUCTION}

Rivers are a type of running water ecosystem, fed by many smaller tributaries which collectively form a catchment basin (Hynes 1970). Rivers represent important freshwater habitats, connecting inland areas to the world's oceans, typically with unidirectional flows. Moreover, rivers represent the interface between land and water (Hynes 1975), with riparian zones serving as rich transitional habitats between ecotones within catchments (Pusey \& Arthington 2003). The world's rivers have incredible biodiversity (Allan \& Flecker 1993), with some rivers regarded as global biodiversity 'hot spots' (Myers et al. 2000), despite the fact that at any one time they only contain a minuscule proportion $(0.006 \%$ by volume) of the world's freshwater (Shiklomanov 1993). Freshwater biodiversity in general is rich (Poff et al. 2001), partic- 
ularly with respect to invertebrates, amphibians and fish, but our knowledge of freshwater biodiversity is incomplete (Allan \& Flecker 1993, Dudgeon et al. 2006). However, it is well accepted that freshwater ecosystems, including rivers, represent some of the most endangered ecosystems in the world (e.g. Dudgeon 1992). Indeed, declines in biodiversity tend to be greater in fresh waters than in most other habitats (Sala et al. 2000). The ecological attributes of rivers are shaped largely by biogeochemical processes, and the morphology of rivers is strongly influenced by geology and climate (Imhof et al. 1996, Ward 1998). Rivers are also inherently variable along their length and through time, and this has contributed to the evolution of organisms that are highly adapted to dynamic conditions (Giller \& Malmqvist 1998).

Riverine ecosystems and their biological components, including fish (Holmlund \& Hammer 1999), provide many valuable ecosystem services. Perhaps it is partly for that reason that humans have long been drawn to settle adjacent to rivers in order to obtain water for irrigation and drinking, to generate hydroelectricity, transport of goods and services, collect food and for recreation. There are also a number of inherent biophysical characteristics that make running water ecosystems particularly susceptible to degradation and biodiversity loss, not the least of which is the fact that because of the unidirectional flow, activities upstream (e.g. pollution, water withdrawals, barriers) influence areas downstream (Malmqvist \& Rundle 2002). The threats facing rivers and their associated biodiversity can be broadly classified as habitat degradation (a major driver), water pollution, invasive species, flow modification and overexploitation, with large-scale environmental changes such as nutrient loading, warming, and shifts in precipitation and runoff patterns, superimposed upon all 4 of these threat categories (Dudgeon et al. 2006, Vörösmarty et al. 2010). Of course, the underlying driver for all of these threats is human activity. Fish are particularly susceptible to the aforementioned threats for several reasons. First, fish are often top predators in riverine systems, so changes in food web structure often cascade up to influence the most visible (large) and charismatic species (Power 1990). In addition, fish have very specific environmental tolerances and habitat requirements, particularly for spawning and early life history (Moyle \& Leidy 1992). Changes in environmental conditions, habitat or ability to access habitats either laterally (e.g. floodplain pools) or longitudinally (e.g. upstream/downstream migrations) can have devastating consequences on fish populations (Richter et al. 1997).
It is because of the many overlapping, and in some cases synergistic, threats that freshwater fish represent some of the most imperilled taxa on the planet (Ricciardi \& Rasmussen 1999). Not surprisingly, as part of regional and international (i.e. IUCN Red List) threat assessments, many riverine fish have been characterized at some level of imperilment (Leidy \& Moyle 1997). Although much effort has been devoted to identifying the threats faced by river fish (see Dudgeon et al. 2006), there has been less effort devoted to identifying the factors that hinder our ability to conserve and restore river fish populations and their watersheds. Therefore, the objective of this paper is to identify and discuss 10 general factors (which can also be viewed as research and implementation needs) that may hinder the ability to enable effective conservation action for endangered river fish. The paper is also intended to introduce and contextualize a series of papers in a Theme Section on endangered river fish that appeared in Endangered Species Research in 2011 and 2012.

\section{FACTORS HINDERING CONSERVATION AND RESTORATION OF RIVERINE FISH POPULATIONS}

\section{Limited information on basic taxonomy and life history requirements of riverine fishes}

Globally, the faunal assemblages of many riverine ecosystems have not been rigorously assessed. In some cases, the only information known about a given fish species is its name and a basic morphological description. In other cases, lack of taxonomic clarity hinders development of effective conservation strategies (Hogan 2011). Other species have yet to be discovered, particularly in developing countries and regions that are difficult to access (e.g. South American and Asian forested regions; see Dudgeon 1992, Junk \& Soares 2001, Kang et al. 2009), and some species could go extinct without our knowledge. Not unlike other fields (Wheeler 2004), there appears to be waning interest in fish taxonomy and systematics (i.e. ichthyology; Chakrabarty 2010), as well as the maintenance of collections, which is further limiting our ability to evaluate and conserve the fish biodiversity in running waters (Wheeler 1995). An absence of such information on the true magnitude of fish biodiversity in rivers should not be used as an excuse for inaction, but it is a deficiency that may need to be rectified. In the marine realm, the identification and cataloguing of species is regarded as sufficiently 
important to result in the formation of an international research project called the Census of Marine Life (Yarincik \& O'Dor 2005). However, we are unaware of similar efforts on a global scale in freshwater.

Beyond having a species list with basic taxonomic information and ideally some information on the abundance of river fish, another prerequisite to effective conservation is knowledge of fish natural history. Such basic information as food preferences (Butler \& Wooden 2012, this Theme Section) and critical habitat requirements (both at micro- and macro-scales; Hahn et al. 2011, Knight et al. 2012, McRae et al. 2012, Spindler et al. 2012, all this Theme Section) are lacking for many riverine fish, including those that are imperiled. As habitat is the building block for fish populations, it is essential to understand which habitats are used for feeding (Butler \& Wooden 2012, Spindler et al. 2012) at different life-stages and spawning (McRae et al. 2012) in order to enable designation and protection of critical habitats (Knight et al. 2012). Also needed is information on environmental tolerances for physiochemical parameters such as dissolved oxygen, water temperature, $\mathrm{pH}$ and turbidity. Such information may be used to predict how fish will respond to proposed development activities (e.g. a hypolimnetic dam flow), conservation actions (e.g. establishment of buffer strips), or environmental change. Essentially, there is a need for extensive research (much of which is descriptive) on fish-environment relationships and the factors that influence growth, reproductive success, offspring development (e.g. Kemp 2011, this Theme Section), and survival (e.g. Hasler et al. 2011, this Theme Section). Other basic information on life-history and reproductive biology including age-at-maturation and fecundity often do not exist for imperiled species. In contemporary fisheries management, such information is the basis for modeling and selection of various management actions. For example, in many high biodiversity countries managers need data on growth, reproductive success and survival to understand how exploitation influences population status, but such data are often not available for highly vulnerable (i.e. endangered) species (Jensen et al. 2009).

\section{Lack of appreciation for the various scales on which river fish move/migrate}

Many fishes need lateral and longitudinal connectivity of rivers to meet their life-history requirements, but the scale at which these connections are needed is still unclear (Fausch et al. 2002). Because humans have altered the connectivity through channelization, levee and dam construction, dewatering of floodplains, and other activities, populations of large river fishes have declined or been extirpated. The primary connections lost by the alterations include longitudinal connection of the main channel caused by dams and diversions, and lateral connection of the river to its floodplain by dewatering, agriculture, and levee construction. Both of these connections operate at multiple spatial scales.

Longitudinal connectivity is often lost in rivers, particularly at large spatial scales. Of the 122 North American warmwater rivers discussed in Paukert \& Galat (2010), 68\% have at least one dam on the main channel. Many fish make long distance migrations during spawning. For example, North American paddlefish can move over $300 \mathrm{~km}$ (Jennings \& Zigler 2009) but are now restricted by dams in the main channel and tributaries of large rivers in the Mississippi River basin. Diadromous fish require migration corridors that extend from sea to river (e.g. Hasler et al. 2011, Jepsen et al. 2012, Mateus et al. 2012, Walter et al. 2012, all this Theme Section). In addition, even small-bodied, pelagic fishes may need at least 100 to 300 river $\mathrm{km}$ to sustain populations (Perkin \& Gido 2011). However, at smaller spatial scales, connectivity is still needed to meet many life-history requirements of river fishes (Winemiller et al. 2010). Resource use may occur at these smaller spatial scales and be influenced by food availability, water temperature, and suitable habitats that may be found in patches within a river. Therefore, riverine fish conservation needs to include both a local spatial scale and broad spatial scales when considering longitudinal connectivity of rivers. Several species of freshwater fish, including sturgeon, salmon, anguillid eels, pimelodid and pangasiid catfish clearly make long distance migrations of hundreds if not thousands of $\mathrm{km}$ (Barthem \& Goulding 1997, Lucas \& Baras 2001, Carolsfeld et al. 2003, Hahn et al. 2011, Hogan 2011). In other cases, the challenge is to determine if a species consists of many localized stocks making short distance movements or highly mobile stocks making long-distance migrations.

Determining the scale of freshwater fish migrations remains a research priority, particularly for imperiled species. Such knowledge is essential to inform the placement of fishways at migration barriers, although our knowledge of fishway design for nonsalmonids is lacking (e.g. Mateus et al. 2012). There are relatively few studies of non-salmonid swimming 
abilities to inform biological design criteria or studies of existing fishways to evaluate their effectiveness, despite river connectivity being a primary concern for non-salmonids (Pasbrig et al. 2012, this Theme Section). For example, Thiem et al. (2011, this Theme Section) studied imperiled lake sturgeon at a fishway that was regarded as successful because individuals were captured in a trap at the top, but a telemetry study revealed that passage efficiency was actually closer to $35 \%$ as many fish that encountered the fishway failed to fully ascend it. It is worth noting that even for the comparatively well-studied salmonids, there still are problems with fish passage at barriers (Baisez et al. 2011, this Theme Section). Improving our understanding of fish passage design criteria (both when they are needed and how they should be designed and operated) is critical for maintaining longitudinal connectivity. In addition, efforts to eliminate barriers could also prove effective in restoring populations of endangered river fish (e.g. Jepsen et al. 2012).

Lateral connection from a main channel to its floodplain at local spatial scales is also needed to maintain imperilled river fishes (Bayley 1995, Fernandes 1997). At the local spatial scale, the connection of a river to its floodplain may provide off-channel habitats for foraging, food supply, and spawning (Junk et al. 1989, Lorenz et al. 1997); these are often considered primary factors in the decline and imperilment of river fishes, and possibly also of migratory fish that access those reaches (assuming longitudinal connectivity is present). However, a few localized lateral connections to endangered river fishes may not provide the same benefits as lateral connections throughout an entire riverine network. Although lateral connections between the main channel and floodplains throughout a river network likely would provide access to nutrients and habitats for imperilled river fishes, these fishes may still need to have longitudinal access to these floodplains. The lateral connection to a floodplain may not be very useful if migratory fishes from the main channel are prevented from accessing the floodplain by a downstream dam or diversion. Therefore, large river fishes need connectivity to floodplain habitats (Junk et al. 1989) but longitudinal connectivity is also necessary for fluvial specialist fishes that primarily use main channel, flowing water habitats (Galat \& Zweimüller 2001).

Challenges to maintaining riverine connectivity include both biological and sociological aspects. Managers of large rivers may need to recognize that these are open systems that often cross political boundaries such as counties, states or provinces, or countries and therefore conservation may have to occur across these interjurisdictional boundaries. A biological challenge is that reconnecting riverine networks may allow migration of aquatic invasive species, release of upstream contaminants trapped in sediments, or excess nutrients. Therefore, managers may need to consider the cost and benefit of reconnections of large rivers as this may provide opportunities for native fish migration, but will also allow the transfer of undesirable products and organisms.

\section{Limited understanding of fish-flow relationships}

The flow regimes (magnitude and duration) of freshwater rivers are a key element for many lifehistory stages of riverine fishes and a primary driver of river ecosystems. The concept of environmental flows is a promising approach to maintenance of freshwater biodiversity and ecosystem services (Arthington et al. 2010). However, river flows have been severely altered in rivers worldwide. Dynesius \& Nilsson (1994) determined that discharge in $77 \%$ of the world's rivers is altered. Many have argued that rivers and streams need a natural flow regime to facilitate ecological function and biotic integrity (e.g. Poff et al. 1997). However, the natural flow regime encompasses many factors such as magnitude, frequency, duration, timing, and rate of change and it is often difficult to directly link 1 aspect of river flows to a fish response. Many metrics and indicators have been used to classify stream flow (Olden et al. in press), but often these classifications use many redundant metrics (over 150; Olden \& Poff 2003). Most of the research related to flow and fishes is linked to spawning and recruitment. Riverine fish spawning may be linked to increased spring flows (e.g. Paukert \& Fisher 2001, Winemiller 2005, Hasler et al. 2011), but low flows may be important to other species (e.g. Humphries et al. 1999). Therefore, the relationship between flows and riverine fishes is often species specific (Paukert \& Galat 2010). In addition, the direct link between river fish persistence, growth, recruitment, or other life histories and specific flow metrics is often unknown. Some of the riverine systems that have not been dammed (e.g. the Mekong) lack information on fish-flow relationships, which impedes our ability to develop effective mitigation measures for future dams. Unfortunately, endangered fish are sufficiently rare that they are often not used in the study of fish-flow relationships, with the result that there is a tendency to rely on information generated from surrogates. 
Restoring natural flow regimes has been proposed as a useful measure for dealing with non-native fish invasions. Although mimicking the natural flow regime may enhance native fish recruitment, it does not necessarily reduce non-native fish recruitment, particularly for highly fecund small-bodied nonnative fishes (Propst \& Gido 2004). Therefore, identifying the mechanisms and specific aspects of flow that help maintain native river fishes may be needed to maintain these native populations. Ideally, knowing the natural dynamics of river systems prior to human alterations would help in the effort, but knowledge of pre-human settlement conditions is rarely available.

\section{Limited understanding of seasonal aspects of river fish biology}

In north-temperate, montane and sub-polar regions characterized by lengthy cold winters with ice and snow cover, there is a paucity of information on the biology of fish during the winter. Given that winter represents a very interesting and challenging time of year that exerts a strong selective pressure on individual survival for many species as well as community structure (Suski \& Ridgway 2009), there is a need for information on river fish biology during that period. In addition, river ice conditions can directly influence fish behavior and survival as well as alter habitat features (Brown et al. 2011). In the southern hemisphere and some tropical regions in the northern hemisphere, seasonal monitoring orients around the dry and wet (or monsoon) periods. In those regions there tends to be additional fisheries research during the moderate transition periods (i.e. between wet and dry seasons), but comparatively little research during the extremes of the wet or dry seasons (but see Winemiller 1990, Winemiller \& Jepsen 1998). The wet season, associated floods, and the formation of backwater areas is known as being critical for riverine fish so there have certainly been some research efforts during that period (e.g. Hocutt \& Johnson 2001, Dudgeon 2005). There is increased study of seasonal movement, habitat selection, site fidelity, and fish assemblage structure of imperilled river fishes (e.g. Modde \& Irving 1998, Stancill et al. 2002). However, these studies are often observational and correlative and there is still a limited understanding of the mechanisms for seasonal shifts in fish populations. Many of these studies focus on spawning season, but very little research exists for rivers that spans the entire year in seasonally cold or wet and dry areas (Welcomme 1985).

\section{Predicting responses of river fish and river ecosystems to both environmental change and restoration/management actions}

Riverine systems have already been altered as a result of environmental change at a variety of scales. Most notably perhaps is the expectation that climate change will alter both river flows and temperatures. Given the important role of temperature for ectothermic animals such as fish (Brett 1971), environmental changes likely will have an effect on fish and it is necessary to predict such changes to facilitate adaptation/management strategies. Already, a variety of coldwater riverine fish are exhibiting evidence of climate change impacts. For example, Baisez et al. (2011) documented significant delays and mortality associated with high river temperatures for upstream migrating Atlantic salmon. Walter et al. (2012) advocate research efforts to identify the hydrological conditions necessary to positively impact fish recruitment under future climate conditions. In some jurisdictions, efforts have been made to predict the effects of development activities (e.g. dams) on river fish, this being a critical component in the evaluation of the true cost of a development project.

River managers and ecologists are often attempting to restore river function and native species through various management actions. Many of these actions are at smaller spatial scales (e.g. construction of wing dikes, bank stabilization, instream fish habitat structures) but some are at larger scales (e.g. Kissimmee River, Florida; Whalen et al. 2002). In addition, other modifications may be at a local scale but have broader scale impacts. For example, dams are being removed throughout the USA and are reconnecting river systems. However, these restoration projects are often either not evaluated or have no clear objectives and metrics for success (Palmer et al. 2005), are confounded by natural variability, or have shown limited success (Palmer et al. 2010). Pretty et al. (2003) found that fish diversity and abundance did not differ between rehabilitated (i.e. creation of artificial riffles and flow deflectors) and control reaches in $13 \mathrm{UK}$ rivers. Similarly, Schloesser et al. (in press) also found that notching wing dikes (to diversify river habitats to benefit native fishes) did not increase the occupancy or abundance of native fishes in a $1200 \mathrm{~km}$ reach of the Missouri River, USA. These are examples of correlative studies relating river restoration to metrics of fish abundance. However, there is little research on the mechanisms that link river restoration to increased native fish abundance, spawning, or other life histories (but see Roni et al. 2010). 
One primary challenge with evaluating restoration actions is that environmental variability is often very high in river systems, making it difficult to identify how an imperiled species restoration or management action has affected riverine fishes when other factors unrelated to the action also need to be considered. Changes in local or broad-scale climate that may affect stream temperature and flow may dictate fish responses (e.g. movement, spawning, and/or recruitment) and thus may confound management actions. Ideally, large-scale experiments and replication may help identify mechanisms for restoration. However, experimental or mechanistic evaluations of large river restoration are very difficult due to lack of replications. Experimental replication is a challenge in restoration projects because it is often not feasible to conduct experiments in numerous large rivers due to cost, scale, and because multiple use of rivers (e.g. navigation, recreation, agriculture) prohibit these actions. However, the use of adaptive resource management (Walters 2001) to evaluate large-scale restoration is becoming more popular when replication and multiple use are prohibitive. The process of adaptive resource management holds promise in large river systems and is now being used to evaluate restoration programmes throughout the United States (Doyle \& Drew 2008). In large riverine systems where multiple stakeholders are involved in the decisionmaking process the use of adaptive management to help restore systems may be a viable alternative.

\section{Limited understanding of the ecosystem services provided by river fish}

Rivers provide important ecosystem goods and services, including irrigation, recreation, transportation, hydroelectric power, bird and wildlife habitat, and food security (Postel \& Carpenter 1997). River fish, in particular, play a major, though often underappreciated, role in providing ecosystem services (reviewed in Holmlund \& Hammer 1999), such as transportation of nutrients (Schindler \& Scheuerell 2002), disease control (Stauffer et al. 1997), seed dispersal (Goulding et al. 1996, Barthem \& Goulding 1997), and food supply. In tropical regions especially, river fish are an important source of food. The Mekong River Basin, for example, produces over 2 million metric tonnes of fish per year, making it the most productive inland fishery in the world. The total harvest is valued at US $\$ 3.6$ billion (i.e. $3.6 \times 10^{9}$ ) to 6.5 billion annually (Ferguson et al. 2011). Such basin-wide values have not been calculated for many other regions, but the importance of river fish is likely to be substantial. In communities along the Madeira River in Bolivia (and in many communities throughout the Amazon basin) fish are the largest source of protein in the diet of local people (Boischio \& Henshel 2000, Dorea 2003).

While the value of river fish may serve as an incentive to better manage freshwater ecosystems and fisheries (Hoeinghaus et al. 2009), this is not always the case. First, few river basins have been assessed for the value that their ecosystems services provide. Second, many systems have already been altered, and so identifying and valuing potential ecosystem services may be difficult. However, in areas where potential values have been determined, they are often significant. For example, Loomis et al. (2000) measured the economic value of lost ecosystem services on a $72 \mathrm{~km}$ reach of the Platte River, USA, and determined that services such as water purification, erosion control, and recreation have a value of between US\$ 19 and 70 million dollars. Similarly, Hoeinghaus et al. (2009) examined the impact of impoundments on an important ecosystem service (artisanal fisheries) and found that, post impoundment, the effort needed to produce fish increased, while fisheries value decreased. Third, the value of ecosystem goods and services may not always be factored into management or development decisions, even when values for the goods and services exist. Recent plans to dam the mainstream Mekong River, despite an estimated loss of US\$274 billion of ecosystem services, demonstrate that political decisions sometimes trump arguments based on value of river fish as an ecosystem good (Dugan et al. 2010, Costanza et al. 2011). Thus, lack of knowledge and appreciation of the ecosystem services provided by river fish is a significant challenge to their conservation (Beard et al. 2011).

\section{River fish and their habitats are inherently difficult to study}

Rivers are particularly challenging environment in which to study fish (Casselman et al. 1990). Flowing water coupled with variable and often unpredictable depths (from very shallow, i.e. several $\mathrm{cm}$, to reaches that are over $50 \mathrm{~m}$ deep) make rivers not only difficult to sample, but also dangerous. Moreover, many parts of river basins are remote and therefore difficult to access for monitoring and research (Valbo-Jørgensen $\&$ Poulsen 2001). Some sampling tools such as electrofishing are ineffective in high flow environments, deep water (over $3 \mathrm{~m}$ ), turbid water, or systems with 
exceptionally high or low conductivity. SCUBA and snorkelling are used in some rivers but high flows and turbidity can lead to unsafe and ineffective sampling. Many passive fishing gears such as trap nets, hoop nets and gill nets do not work well in high flow or deep waters. Moreover, endangered river fish are rare, so the detection probability of imperiled species is limited and varies by gear type, something that must be accounted for during research and monitoring (Schloesser et al. 2012, this Theme Section). In some regions, explosives or piscicides are used with some success for monitoring, although such lethal sampling techniques should be used with caution when working with endangered species. In large rivers without large amounts of debris, trawl nets can be used. Given the challenges of sampling fish in rivers of all sizes, particularly those that are nonwadeable, there is a general lack of information on the abundance, assemblages and trends in riverine fish communities and particularly endangered species. Obviously, the size of the system, environmental characteristics, sensitivity (i.e. stress, injury, mortality) of an endangered species to interaction with sampling gear, budget and objectives of a given study will dictate the suite of tools that are available for sampling fish, as outlined in Casselman et al. (1990) and Bonar et al. (2009). Beyond sampling fish, the aforementioned challenges also make it difficult to sample habitat characteristics used by fishes.

There are a growing number of technological solutions to studying fish and fish habitat in rivers including imaging tools such as hydroacoustic surveys, DIDSON cameras, and fish tracking systems (e.g. radio and acoustic telemetry). These tools are expensive and there is a level of expertise and capacity needed to use them, but the benefit is that the techniques do not require lethal sampling (Cooke 2008). One of the few studies to employ such methods to date was conducted by Hahn et al. (2011) who used radio telemetry to study fish movement and habitat use in a neotropical river in Brazil and identified a number of challenges involved in the use of this technology. In general, the use of many of the technology-based tools tends to be restricted to developed countries. Moreover, migration/movement studies tend to occur at smaller scales rather than that of the species' entire migratory capacity. There is a need for development and calibration of additional tools for the sampling of riverine fish with an emphasis on tools that can be used in regions where little research on riverine fish has occurred (e.g. developing countries). Also needed are workshops and guidebooks to build capacity in developing countries for use of tools for the study of endangered river fish (e.g. Baras et al. 2002). For endangered river fish, even once data have been collected, a number of analytical challenges remain, such as variable catches, zero catches, poor abundance estimators, or too few fish to develop biological models. There are, however, a growing number of quantitative tools for addressing those challenges inherent to endangered river fish (e.g. see Wenger \& Freeman 2008, Schloesser et al. 2012).

Although collection of data via scientific approaches is fundamental to resource management, people that live along the shores of rivers and rely on river fisheries for their daily survival often have an intimate knowledge of fish biology. As such, river users may be able to provide managers with baseline knowledge (Valbo-Jørgensen \& Poulsen 2001). In a case study on the Mekong River, Valbo-Jørgensen \& Poulsen (2001) conclude that local knowledge is an important complement to biological data, although one which is rarely considered. Stakeholder and traditional knowledge is increasingly being regarded as important in natural resource management. In the context of endangered river fish, such knowledge is likely essential, given the challenges in studying such fish and the dearth of information on their natural history. Unfortunately, in some instances, local knowledge represents the only source of information; however, there are a growing number of approaches for incorporating such knowledge into decisionmaking processes (e.g. Bayesian analyses).

\section{Limited understanding of the human dimension in river fish conservation and management}

Over the last few decades, there have been a number of conceptual and practical advances in the application of social science knowledge and research to natural resource and conservation problems (generally termed human dimensions [Ditton 2004] or conservation social science [Mascia et al. 2003]). Humans are part of ecosystems and often play a dominant role in the threats that face ecosystems and their components such as riverine fish. Moreover, humans may facilitate or impede management or recovery strategies, so it is important to know the expected level of support from stakeholders when implementing conservation actions. Although some have argued that human dimensions research is particularly needed to improve conservation in developing countries (Saberwal \& Kothari 1996), Jacobson \& McDuff (1998) suggest that the same can be said for developed countries. We concur, and believe that 
there is much need and opportunity for the inclusion of human dimensions studies as part of river fish conservation programmes and, more broadly, of river and watershed management.

To date, there has been very little human dimensions research specific to endangered river fish (but see Vaske et al. 1995), although there is more research on general aspects of the human dimensions of river basins and their management. Although we focus our paper on endangered river fish, these animals are part of the broader ecosystem, and given the range and complexity of issues associated with rivers, the concept of integrated water resource management (IWRM) is often regarded as a necessity in which biophysical and socio-economic elements are integrated (Newson 2004, Beard et al. 2011). A key component of IWRM is setting priorities for river restoration and management (Newson 2004); however, there can be conflict between biophysical and social criteria (Fryirs et al. 2007, Koehn \& Lintermans 2012, this Theme Section) when setting priorities. Stakeholders have a wide range of motivations for their support for, or involvement in, river conservation activities, so knowledge of the heterogeneity of perspectives (e.g. cultural, religious, political) may be needed to identify approaches that recognize and balance this range of priorities and motivations (Fryirs et al. 2007). Understanding the social impediments to river conservation, such as social ties to floodplain agriculture protected by levees that prohibit floodplain reconnections, is a prerequisite to the identification of win-win scenarios for stakeholders and endangered river fish. There can also be conflict among stakeholders, and human dimensions research includes efforts to understand the basis of conflict such that it can be managed and diffused. Another major contribution of human dimensions research is to further our understanding of the social forces that lead to environmental change (Clausen \& York 2008). To that end, when the factors responsible for declines in, or threats to, river fish are known, it would be useful to know what influences the level of support that could be expected from stakeholders when implementing various management strategies.

Also needed is a discussion about the type of political, economic, and social organization that may be required to create a society where human well-being and ecological integrity are maintained (Clausen \& York 2008) before more imperiled riverine fishes become extirpated. Castle (2001) suggested that for the Columbia River, the reestablishment of fish spawning runs to historical levels is likely unattainable and represents a more complex problem than adjusting a trade-off between environmental preservation and economic development. Castle's (2001) findings further emphasize the need for information on how different stakeholders view endangered river fish and what they would be willing to do (trade-off) to ensure they are protected or restored. One tool that human dimensions scientists may use is modelling of the economic value of investment in different types of management actions. Clearly the needs for human dimensions research are great and they extend beyond simply focusing on endangered river fish to include integrated water management and how river fish are perceived and prioritized by different stakeholders in that framework.

\section{Efforts focused on a single species often fail to address broader-scale problems}

A primary challenge with riverine species management and conservation is to ensure that river ecosystems - and not just a single species or subset of species - are conserved. Efforts to conserve one species often may not address the broader issues that have been implicated in the decline of other fishes (see Knight et al. 2012). Because many river fishes are imperiled, management actions focus on these species through mitigation activities. As an example, stocking (i.e. conservation aquaculture; Drauch Schreier et al. 2012, this Theme Section), translocating, or reintroducing an endangered species alone may not address the issue that caused the lack of natural reproduction (Lintermans 2012, Paragamian 2012, both this Theme Section). Monitoring and restoration programs often dictate success based on recovery or stability of a species listed by government agencies as endangered or threatened. Indeed, very few papers on endangered river fish incorporate data for more than a few fish species (but see Koehn \& Lintermans 2012, Schloesser et al. 2012). However, biological integrity of rivers incorporates species diversity, composition, and function (Karr 1981). Many restoration activities may not necessarily achieve the goal of increasing biological integrity because some fish species use only certain habitats (e.g. Galat \& Zweimüller 2001) which may not be the target for restoration. This is often the case with habitats that are inundated after dam construction. In general, efforts to address imperiled species in reservoir habitats have been lacking although there are some cases where coordinated enhancement and monitoring 
programmes have had some success (Lintermans 2012). Rivers are complex systems that interact with the environment both longitudinally and laterally. Because these interactions are complex and often species specific, more restoration efforts may need to incorporate broader biological responses than those of a single species (or suite of species) to be considered successful in terms of the restoration of a riverine system (Koehn \& Lintermans 2012).

\section{Limited effectiveness of governance structures that address river fish populations and rivers that cross multiple jurisdictions}

For migratory fish that cross international borders or fish that occur as shared stocks in international river basins, one of the greatest management needs is collaborative action to regulate fisheries and maintain river health. Even within a single country, there can be challenges with multi-jurisdictional overlap among different levels of government (Koehn \& Lintermans 2012). Unfortunately, regulation and management of freshwater fish, including imperiled freshwater fish, do not often occur at an international scale. This may be, at least in part, because management of inland waters (and freshwater biodiversity) has historically been viewed as a sovereign issue. Nonetheless, transboundary governance and cooperation are urgently needed for many species (Valbo-Jørgensen et al. 2008), including diadromous species such as salmon, sturgeon (e.g. Paragamian 2012), and eels as well as obligate freshwater species that migrate long distances, such as catfish of the Mekong and Amazon Rivers or dorado in south American systems (e.g. Hahn et al. 2011). In the absence of effective regulation, transboundary, migratory fish may be particularly susceptible to a wide range of threats: overfishing (which often occurs at rearing and spawning sites, as well as in migration corridors), loss of habitat, loss of connectivity between critical habitats, and alteration of the river itself (e.g. water quantity, quality, flow, and temperature). The large-scale decline of many transboundary, migratory fish highlights the seriousness of this issue (Casselman \& Cairns 2009, Jaric et al. 2009, Limburg \& Waldman 2009).

While lack of effective governance structures may be an obstacle to successful management of migratory, transboundary fish stocks in many locations, mechanisms do exist to facilitate international cooperation (Coates et al. 2000). Mechanisms include international conventions such as the Convention on Biological Diversity (CBD), the Convention on Inter- national Trade in Endangered Species of Wild Fauna and Flora (CITES), and the Convention on Migratory Species (CMS) as well as regional river basin agreements, like the Mekong Agreement, and frameworks established by international organizations such as the Food and Agriculture Organization's (FAO) Code of Conduct for Responsible Fisheries. These mechanisms are potentially powerful tools for management of river fish, but most suffer from shortcomings that have limited their effectiveness. For example, CITES focuses almost exclusively on species in international trade and thus is often not an appropriate management tool for species that are not subject to international trade (including many highly threatened species). In contrast, CMS is designed specifically to facilitate the management of transboundary migratory species but is limited by the relatively small number of taxa listed and the restricted geographical distribution of its signatories. CMS is also limited by lack of knowledge of the spatial ecology of species, since in order to be listed in the Appendices of CMS a species must be shown to migrate across an international border. Regional agreements, such as the Mekong Agreement and the Great Lakes Fishery Commission have been effective facilitators of fisheries management efforts but their geographic reach is by definition limited, and such agreements are not yet widespread enough to deal with lack of governance on a global scale.

While each case is unique, it is clear that the management and conservation status of many freshwater fish species - on every continent with transboundary rivers - could be improved through international cooperative efforts. The effectiveness of governance structures at facilitating management of transboundary stocks, including those that are endangered, depends on many of the factors discussed above: reliable information on life history and migratory behavior; information on the relationship between flow, fish ecology and fisheries production; an appreciation of the value of fisheries and other ecosystem services; and capacity to predict how management measures will impact fish stocks. In this sense, many of the obstacles to effective management and conservation (e.g. lack of data on life history, general difficulty of study, lack of appreciation of value of freshwater fisheries) reinforce one another, illustrating the challenges ahead and the need to confront these issues in a comprehensive manner whenever possible. Relatedly, the above discussion assumes that science is the basis for decision making and that the science-policy interface is receptive to knowledge mobilization (Brosnan 1995). Unfortunately, that is not always the case, and 
this can lead to inaction or misinformed action related to the conservation of endangered river fish.

\section{CONCLUSIONS}

In this paper we identified and discussed 10 general factors that we believe may hinder the conservation and management of endangered river fishes. Each of these factors can also be viewed as a research or implementation need that may need to be addressed to enable effective conservation action. These factors were identified through a review of the literature and through an examination of the themes that emerged from the papers published as part of the Theme Section on Endangered River Fish in Endangered Species Research. Although our focus was on endangered river fishes, the issues that we discuss are germane to many river fishes and river systems. Failure to address the issues identified in this paper will further delay our ability to respond to the crisis facing river fishes globally. There is need for immediate and concerted efforts to address knowledge gaps related to the biology of river fish and their environmental requirements as well as the human dimension of river fish. One promising approach is to better characterize the ecosystem services provided by river fish such that they are ascribed a meaningful value that can be used when interacting with decision makers. Governance structures for river management may be most effective if they recognize the connectivity of systems and the fact that fish do not respect geo-political boundaries. Moreover, there is a need to increase capacity for both science and management in developing countries where currently there are many threats facing river fish. Management strategies that are holistic and focus not only on endangered river fish, but also on the broader ecosystem (usually on a basin scale) will be necessary for future conservation of these systems. Of course no solution will be effective in any of these river basins unless it is implemented through cooperation across social, economic, and political boundaries using an ecosystemic approach. However, imperiled river fishes require recovery and management plans that may include costly interventions such as the use of captive breeding (e.g. Drauch Schreier et al. 2012) and stock enhancement activities. We hope that the factors identified here will be addressed by the scientific and management communities as well as stakeholders so that there can be collective progress on the recovery of endangered river fish populations and protection and sustainable management of those populations that risk endangerment in the future. The papers presented as part of the Theme Section on endangered river fish go some way to addressing these issues but there is certainly much more needed.

Acknowledgements. We thank Penny Kuhn (from InterResearch) for supporting the preparation of the Endangered Species Research Theme Section on endangered river fish. We also thank the authors and referees who contributed to the Theme Section as well as 3 anonymous referees who provided valuable input on this paper. S.J.C. was supported by the Canada Research Chairs Program, the Ontario Ministry of Research and Innovation, the Canadian Wildlife Federation, and the Natural Sciences and Engineering Research Council of Canada. The Missouri Cooperative Fish and Wildlife Research Unit (C.P.) is jointly sponsored by the Missouri Department of Conservation, the University of Missouri, the US Geological Survey, the US Fish and Wildlife Service, and the Wildlife Management Institute.

\section{LITERATURE CITED}

Allan JD, Flecker AS (1993) Biodiversity conservation in running waters. Bioscience 43:32-43

Arthington AH, Naiman RJ, McClain ME, Nilsson C (2010) Preserving the biodiversity and ecological services of rivers: new challenges and research opportunities. Freshw Biol 55:1-16

> Baisez A, Bach JM, Leon C, Parouty T, Terrade R, Hoffmann M, Laffaille P (2011) Migration delays and mortality of adult Atlantic salmon Salmo salar en route to spawning grounds on the River Allier, France. Endang Species Res 15:265-270

Baras E, Benech V, Marmulla G (2002) Outcomes of a pilot fish telemetry workshop for developing countries. Hydrobiologia 483:9-11

Barthem R, Goulding M (1997) An unexpected ecosystem: the Amazon as revealed by fisheries. Missouri Botanical Garden Press, St. Louis, MO

Bayley PB (1995) Understanding large river-floodplain ecosystems. Bioscience 45:153-158

> Beard TD, Arlinghaus R, Bartley D, Cooke SJ, de Silva S, McIntyre P, Cowx IG (2011) Ecosystem approach to inland fisheries: research needs and implementation strategies. Biol Lett 7:481-483

Boischio AA, Henshel D (2000) Fish consumption, fish lore, and mercury pollution-risk communication for the Madeira River people. Environ Res 84:108-126

Bonar SA, Hubert WA, Willis DW (eds) (2009) Standard methods for sampling North American freshwater fishes. American Fisheries Society, Bethesda, MD

Brett JR (1971) Energetic responses of salmon to temperature. A study of some thermal relations in physiology and ecology of sockeye salmon (Oncorhynchus nerka). Am Zool 11:99-113

Brosnan DM (1995) Bridging the gaps among ecology, law, and policy. Wildl Soc Bull 23:333-337

Brown RS, Hubert WA, Daly S (2011) A primer on winter, ice, and fish: what fisheries biologists should know about winter ice processes and stream-dwelling fishes. Fisheries 36:8-26 
Butler GL, Wooden IJ (2012) Dietary habits of a large, longlived endangered Australian percichthyid, the eastern freshwater cod Maccullochella ikei. Endang Species Res 16:199-209

Carolsfeld J, Harvey B, Ross C, Baer A (2003) Migratory fishes of South America: biology, fisheries and conservation status. World Fisheries Trust, World Bank and International Development Research Centre. World Bank, Washington, DC

Casselman JM, Cairns DK (eds) (2009) Eels at the edge: science, status, and conservation concerns. American Fisheries Society Symposium 58. American Fisheries Society, Bethesda, MD

Casselman JM, Penczak T, Carl L, Mann RHK, Holcik J (1990) An evaluation of fish sampling methodologies for large river systems. Pol Arch Hydrobiol 37:521-551

Castle EN (2001) Economic and social change in the fishery. In: Johnston RS, Shriver AL (eds) Microbehavior and Macroresults: Proc 10th Biennial Conference of the International Institute of Fisheries Economics and Trade, July 10-14, 2000, Corvallis, Oregon, USA. International Institute of Fisheries Economics and Trade (IIFET), Corvallis, OR, 2001

Chakrabarty P (2010) The transitioning state of systematic ichthyology. Copeia 2010:513-515

Clausen R, York R (2008) Global biodiversity decline of marine and freshwater fish: a cross-national analysis of social and ecological influences. Soc Sci Res 37: $1310-1320$

Coates D, Poulsen AF, Viravong S (2000) Governance and transboundary migratory fish stocks in the Mekong River Basin. Paper presented at the MRC 3rd Fisheries Technical Symposium, 8-9 December 2000. Mekong River Commission, Phnom Penh

Cooke SJ (2008) Biotelemetry and biologging in endangered species research and animal conservation: relevance to regional, national, and IUCN Red List threat assessments. Endang Species Res 4:165-185

Costanza R, Kubiszewski I, Paquet P, King J and others (2011) Planning approaches for water resources development in the Lower Mekong Basin. USAID, Bangkok

Ditton RB (2004) Human dimensions of fisheries. In: Manfredo MJ, Vaske JJ, Bruyer BL, Field DR, Brown PJ (eds) Society and natural resources: a summary of knowledge prepared for the 10th International Symposium on Society and Resource Management. Modern Litho, Jefferson, MO, p 199-208

Dorea JG (2003) Fish are central in the diet of Amazonian riparians: Should we worry about their mercury concentrations? Environ Res 92:232-244

Doyle M, Drew CA (eds) (2008) Large-scale ecosystem restoration: five case studies from the United States. Island Press, Washington, DC

Drauch Schreier A, Rodzen J, Ireland S, May B (2012) Genetic techniques inform conservation aquaculture of the endangered Kootenai River white sturgeon Acipenser transmontanus. Endang Species Res 16:65-75

Dudgeon D (1992) Endangered ecosystems - a review of the conservation status of tropical Asian rivers. Hydrobiologia 248:167-191

Dudgeon D (2005) River rehabilitation for conservation of fish biodiversity in monsoonal Asia. Ecol Soc 10:15. Available at www.ecologyandsociety.org/vol10/iss2/art15/

> Dudgeon D, Arthington AH, Gessner MO, Kawabata Z and others (2006) Freshwater biodiversity: importance, status, and conservation challenges. Biol Rev Camb Philos Soc 81:163-182

> Dugan PJ, Barlow C, Agostinho AA, Baran E and others (2010) Fish migration, dams, and loss of ecosystem services in the Mekong Basin. Ambio 39:344-348

Dynesius M, Nilsson C (1994) Fragmentation and flow regulation of river systems in the Northern third of the world. Science 266:753-762

> Fausch KD, Torgersen CE, Baxter CV, Li HW (2002) Landscapes to riverscapes: bridging the gap between research and conservation of stream fishes. Bioscience 52:483-498

- Ferguson JW, Healey M, Dugan P, Barlow C (2011) Potential effects of dams on migratory fish in the Mekong River: lessons from salmon in the Fraser and Columbia Rivers. Environ Manag 47:141-159

$>$ Fernandes CC (1997) Lateral migration of fishes in Amazon floodplains. Ecol Freshw Fish 6:36-44

Fryirs K, Hillman M, Spink A (2007) Challenges faced in the integration of science in river management in Australia. In: Wilson AL, Dehaan RL, Watts RJ, Page KJ, Bowmer $\mathrm{KH}$, Curtis A (eds) Proc 5th Australian Stream Management Conference. Australian rivers: making a difference. Charles Sturt University, Thurgoona, p 103-108

> Galat DL, Zweimüller I (2001) Conserving large river fishes: Is the 'highway analogy' an appropriate paradigm? J N Am Benthol Soc 20:266-279

Giller S, Malmqvist B (1998) The biology of streams and rivers. Oxford University Press, Oxford

Goulding M, Smith NJH, Mahar J (1996) Floods of fortune: ecology and economy along the Amazon. Columbia University Press, New York, NY

> Hahn L, Agostinho AA, English KK, Carosfeld J, da Câmara LF, Cooke SJ (2011) Use of radiotelemetry to track threatened dorados Salminus brasiliensis in the upper Uruguay River, Brazil. Endang Species Res 15:103-114

- Hasler CT, Donaldson MR, Sunder RPB, Guimond E and others (2011) Osmoregulatory, metabolic, and nutritional condition of summer-run male Chinook salmon in relation to their fate and migratory behavior in a regulated river. Endang Species Res 14:79-89

> Hocutt CH, Johnson PN (2001) Fish response to the annual flooding regime in the Kavango River along the Angola/Namibia border. S Afr J Mar Sci 23:449-464

> Hoeinghaus DJ, Agostinho AA, Gomes LC, Pelicice FM and others (2009) Effects of river impoundment on ecosystem services of large tropical rivers: embodied energy and market value of artisanal fisheries. Conserv Biol 23: 1222-1231

Hogan Z (2011) Ecology and conservation of large-bodied freshwater catfish: a global perspective. In: Michaletz $\mathrm{PH}$, Travnichek VH (eds) Conservation, ecology, and management of catfish: the second international symposium. American Fisheries Society Symposium 77. American Fisheries Society, Bethesda, MD, p 39-53

> Holmlund CM, Hammer M (1999) Ecosystem services generated by fish populations. Ecol Econ 29:253-268

Humphries P, King AJ, Koehn JD (1999) Fish, flows and flood plains: links between freshwater fishes and their environment in the Murray-Darling River system, Australia. Environ Biol Fishes 56:129-151

Hynes HBN (1970) The ecology of running waters. University of Toronto Press, Toronto

Hynes HBN (1975) The stream and its valley. Verh Int Ver Limnol 19:1-15 
Imhof JG, Fitzgibbon J, Annable WK (1996) A hierarchical evaluation system for characterizing watershed ecosystems for fish habitat. Can J Fish Aquat Sci 53(Suppl 1):312-326

> Jacobson SK, McDuff MD (1998) Training idiot savants: the lack of human dimensions in conservation biology. Conserv Biol 12:263-267

- Jaric I, Lenhardt M, Cvijanovic G, Ebenhard T (2009) Acipenser sturio and Acipenser nudiventris in the Danube-extant or extinct? J Appl Ichthyol 25:137-141

Jennings CA, Zigler SJ (2009) Biology and life history of the paddlefish; an update. In: Paukert C, Scholten G (eds) Paddlefish management, propagation, and conservation in the 21st century: building from 20 years of research and management. American Fisheries Society, Bethesda, MD, p 1-22

> Jensen OP, Gilroy DJ, Hogan Z, Allen BC and others (2009) Evaluating recreational fisheries for an endangered species: a case study of taimen, Hucho taimen, in Mongolia. Can J Fish Aquat Sci 66:1707-1718

> Jepsen N, Deacon M, Koed A (2012) Decline of the North Sea houting: protective measures for an endangered anadromous fish. Endang Species Res 16:77-84

> Junk WJ, Soares MGM (2001) Freshwater fish habitats in Amazonia: state of knowledge, management, and protection. Aquat Ecosyst Health Manag 4:437-451

Junk W, Bayley P, Sparks R (1989) The flood pulse concept in river-floodplain systems. Publ Spec Can Sci Halieut Aquat 106:110-127

Kang B, He D, Perrett L, Wang H, Hu W, Deng W, Wu Y (2009) Fish and fisheries in the Upper Mekong: current assessment of the fish community, threats and conservation. Rev Fish Biol Fish 19:465-480

Karr JR (1981) Assessment of biotic integrity using fish communities. Fisheries 6:21-27

- Kemp A (2011) Comparison of embryological development in the threatened Australian lungfish Neoceratodus forsteri from two sites in a Queensland river system. Endang Species Res 15:87-101

Knight JT, Arthington AH, Holder GS, Talbot RB (2012) Conservation biology and management of the endangered Oxleyan pygmy perch Nannoperca oxleyana Whitley in Australia. Endang Species Res 17:169-178

Koehn JD, Lintermans M (2012) A strategy to rehabilitate fishes of the Murray-Darling Basin, south-eastern Australia. Endang Species Res 16:165-181

Leidy RA, Moyle PB (1997) Conservation status of the world's fish fauna: an overview. In Fiedler PA, Karieva PM (eds) Conservation biology for the coming decade. Chapman \& Hall, New York, NY, p 187-227

> Limburg KE, Waldman JR (2009) Dramatic declines in North Atlantic diadromous fishes. Bioscience 59:955-965

- Lintermans M (2012) Managing potential impacts of reservoir enlargement on threatened Macquaria australasica and Gadopsis bispinosus in southeastern Australia. Endang Species Res 16:1-16

Loomis J, Kent P, Strange L, Fausch K, Covich A (2000) Measuring the total economic value of restoring ecosystem services in an impaired river basin: results from a contingent valuation survey. Ecol Econ 33:103-117

> Lorenz CM, Van Dijk GM, Van Hattum AGM, Cofino WP (1997) Concepts in river ecology: implications for indicator development. Regul Rivers Res Manag 13:501-516

Lucas MC, Baras E (2001) Migration of freshwater fishes. Blackwell Science, Malden, MA
Malmqvist B, Rundle S (2002) Threats to running water ecosystems of the world. Environ Conserv 29:134-153

Mascia MB, Brosius JP, Dobson TA, Forbes BC, Horowitz L, McKean MA, Turner NJ (2003) Conservation and the social sciences. Conserv Biol 17:649-650

Mateus CS, Rodríguez-Muñoz R, Quintella BR, Alves MJ, Almeida PR (2012) Lampreys of the Iberian Peninsula: distribution, population status and conservation. Endang Species Res 16:183-198

> McRae CJ, Warren KD, Shrimpton JM (2012) Spawning site selection in interior Fraser River coho salmon Oncorhynchus kisutch: an imperiled population of anadromous salmon from a snow-dominated watershed. Endang Species Res 16:249-260

> Modde T, Irving DB (1998) Use of multiple spawning sites and seasonal movement by razorback suckers in the Middle Green River, Utah. N Am J Fish Manag 18: 318-326

Moyle PB, Leidy RA (1992) Loss of biodiversity in aquatic ecosystems: evidence from fish faunas. In: Fiedler PL, Jain SK (eds) Conservation biology: the theory and practice of nature conservation, preservation and management. Chapman \& Hall, New York, NY, p 127-169

Myers N, Mittermeier RA, Mittermeier CG, da Fonseca GAB, Kent J (2000) Biodiversity hotspots for conservation priorities. Nature 403:853-858

Newson MD (2004) Integrating the biophysical and social science frameworks for IWRM/IRBM: rationality and reality. In: Webb B, Acreman M, Maksimovic C, Smithers $\mathrm{H}$, Kirby C (eds) Hydrology: science and practice for the 21st century, Vol II. British Hydrological Society, London, p 439-443

> Olden JD, Poff NL (2003) Redundancy and the choice of hydrologic indices for characterizing streamflow regimes. River Res Appl 19:101-121

Olden JD, Kennard MJ, Pusy BJ (in press) A framework for hydrologic classification with a review of methodologies and applications in ecohydrology. Ecohydrology. doi:10.1002/eco.251

Palmer MA, Bernhardt ES, Allen JD, Lake PS and others (2005) Standards for ecologically successful river restoration. J Appl Ecol 42:208-217

Palmer MA, Menninger H, Benhardt ES (2010) River restoration, habitat heterogeneity, and biodiversity: a failure of theory or practice? Freshw Biol 55(Suppl. 1): 205-222

Paragamian VL (2012) Kootenai river white sturgeon: synthesis of two decades of research. Endang Species Res 17:157-167

> Pasbrig CA, Koupal KD, Schainost S, Hoback WW (2012) Changes in range-wide distribution of plains topminnow Fundulus sciadicus. Endang Species Res 16:235-247

Paukert CP, Galat DL (2010) Large warmwater rivers. In: Hubert WA, Quist MC (eds) Inland fisheries management in North America, 3rd edn. American Fisheries Society, Bethesda, MD, p 699-730

Paukert CP, Fisher WL (2001) Spring movements of paddlefish in a prairie reservoir system. J Freshw Ecol 16: 113-124

> Perkin JS, Gido KB (2011) Stream fragmentation thresholds for a reproductive guild of Great Plains fishes. Fisheries 36:371-383

Poff NL, Allan JD, Bain MD, Karr JL and others (1997) The natural flow regime. Bioscience 47:769-784 
Poff NL, Angermeier PL, Cooper SD, Lake PS and others (2001) Fish diversity in streams and rivers. In: Chapin FS, Sala OE, Huber-Sannwald R (eds) Scenarios of future biodiversity. Springer-Verlag, New York, NY, p 315-349

Postel SL, Carpenter SR (1997) Freshwater ecosystem services. In: Daily GC (ed) Nature's services. Island Press, Washington, DC, p 195-214

Power ME (1990) Effects of fish in river food webs. Science 250:811-814

Pretty JL, Harrison SSC, Shepherd DJ, Smith C, Hildrew AG, Hey RD (2003) River rehabilitation and fish populations: assessing the benefit of instream structures. J Appl Ecol 40:251-265

> Propst D, Gido K (2004) Responses of native and nonnative fishes to natural flow regime mimicry in the San Juan River. Trans Am Fish Soc 133:922-931

- Pusey BJ, Arthington AH (2003) Importance of the riparian zone to the conservation and management of freshwater fish: a review. Mar Freshw Res 54:1-16

Ricciardi A, Rasmussen JB (1999) Extinction rates of North American freshwater fauna. Conserv Biol 13:1220-1222

> Richter BD, Braun DP, Mendelson DA, Master LL (1997) Threats to imperiled freshwater fauna. Conserv Biol 11:1081-1093

Roni P, Pess G, Beechie T, Morley S (2010) Estimating changes in coho salmon and steelhead abundance from watershed restoration: How much restoration is needed to measurably increase smolt production? N Am J Fish Manag 30:1469-1484

Saberwal VK, Kothari A (1996) The human dimension in conservation biology curricula in developing countries. Conserv Biol 10:1328-1331

Sala OE, Chapin FS III, Armesto JJ, Berlow R and others (2000) Global biodiversity scenarios for the year 2100. Science 287:1770-1774

Schindler DE, Scheuerell MD (2002) Habitat coupling in lake ecosystems. Oikos 98:177-189

Schloesser JT, Paukert CP, Doyle WJ, Hill TD, Steffensen KD, Travnichek VH (2012) Heterogeneous detection probabilities for imperiled Missouri River fishes: implications for large-river monitoring programs. Endang Species Res 16: 211-224

Schloesser, JT, Paukert CP, Doyle WJ, Hill TD, Steffensen $\mathrm{KD}$, Travnichek VH (in press) Fish assemblages at engineered and natural channel structures in the Lower Missouri River: implications for modified dike structures. River Res Appl doi:10.1002/rra1578

Shiklomanov IA (1993) World fresh water resources. In: Glick PH (ed) Water in crisis. Oxford University Press, Oxford, p 13-24

Spindler BD, Chipps SR, Klumb RA, Graeb BDS, Wimberly MC (2012) Habitat and prey availability attributes associated with juvenile and early adult pallid sturgeon occurrence in the Missouri River, USA. Endang Species Res 16:225-234

Stancill W, Jordan GR, Paukert CP (2002) Seasonal migration patterns and site fidelity of adult paddlefish in Lake Francis Case, Missouri River. N Am J Fish Manag 22:815-824

Stauffer JR, Arnegard ME, Cetron M, Sullivan JJ, Chitsulo LA, Turner GF (1997) Controlling vectors and hosts of parasitic diseases using fishes: a case history of schistosomiasis in Lake Malawi. Bioscience 47:41-49
Suski CD, Ridgway MS (2009) Winter ecology of centrarchid fishes. In: Cooke SJ, Philipp DP (eds) Ecological diversity of centrarchid fishes: basic and applied perspectives. John Wiley \& Sons, Chichester, p 264-292

> Thiem JD, Binder TR, Dawson JW, Dumont P and others (2011) Behaviour and passage success of upriver-migrating lake sturgeon Acipenser fulvescens in a vertical slot fishway on the Richelieu River, Quebec, Canada. Endang Species Res 15:1-11

Valbo-Jørgensen J, Poulsen AF (eds) (2001) Using local knowledge as a research tool in the study of river fish biology: experiences from the Mekong. Environ Dev Sustain 2:253-376

Valbo-Jørgensen J, Marmulla G, Welcomme RL (2008) Migratory fish stocks in transboundary basins-implications for governance, management, and research. In: Lagutov $\mathrm{V}$ (ed) Rescue of sturgeon species in the Ural River basin. NATO Science for Peace and Security Series C: Environmental Security. Springer, Amsterdam, p 61-86

Vaske JJ, Donnelly MP, Lyon M (1995) Knowledge, beliefs and attitudes toward the endangered fish of the Colorado River Basin. (HDNRU Rep. No. 20). Colorado State University, Human Dimensions in Natural Resources Unit, Fort Collins, CO

Vörösmarty CJ, McIntyre PB, Gessner MO, Dudgeon D and others (2010) Global threats to human water security and river biodiversity. Nature 467:555-561

Walter RP, Hogan JD, Blum MJ, Gagne RB, Hain EF, Gilliam JF, McIntyre PB (2012) Climate change and conservation of endemic amphidromous fishes in Hawaiian streams. Endang Species Res 16:261-272

Walters C (2001) Adaptive management of renewable resources. Blackburn Press, Caldwell, NJ

> Ward JV (1998) Riverine landscapes: biodiversity patterns, disturbance regimes, and aquatic conservation. Biol Conserv 83:269-278

Welcomme RL (1985) River fisheries. FAO Fisheries Tech Pap 262. FAO, Rome

> Wenger SJ, Freeman MC (2008) Estimating species occurrence, abundance, and detection probability using zeroinflated distributions. Ecology 89:2953-2959

> Wheeler QD (1995) Systematics, the scientific basis for inventories. Biodivers Conserv 4:476-489

- Wheeler QD (2004) Taxonomic triage and the poverty of phylogeny. Philos Trans R Soc Lond Biol Sci 359:571-583

Whalen PJ, Toth LA, Koebel JW, Strayer PK (2002) Kissimmee River restoration: a case study. Water Sci Technol 45(11):55-62

> Winemiller KO (1990) Spatial and temporal variation in tropical fish trophic networks. Ecol Monogr 60:331-367

Winemiller K (2005) Floodplain river food webs: generalizations and implications for fisheries management. In: Welcomme R, Petr T (eds) Proc 2nd International Symposium on the Management of Large Rivers for Fisheries, Vol 2. Mekong River Commission, Phnom Penh, p 285-312

Winemiller KO, Jepsen DB (1998) Effects of seasonality and fish movement on tropical river food webs. J Fish Biol 53(Suppl A):267-296

Winemiller KO, Flecker AS, Hoeninghaus D (2010) Patch dynamics and environmental heterogeneity in lotic ecosystems. J N Am Benthol Soc 29:84-99

> Yarincik K, O'Dor R (2005) The Census of Marine Life: goals, scope and strategy. Sci Mar 69(Suppl 1):201-208 